\title{
Geç Dönem Osmanlı Sağlık Yapılarının Gelişiminin Adana Vilayeti Örneği Üzerinden İncelenmesi*
}

\author{
Development of Late Ottoman Health Structures and Investigation on Adana \\ Province Sample
}

\author{
Nur Umar" $\odot$, Fatma Zehra Sarr ${ }^{*+*} \odot$
}

\section{Öz}

Sosyal devlet anlayışını benimseyen Anadolu Türk Devletleri halk sağlığına önem vermiş ve bu doğrultuda sağlık yapılarını inşa etmişlerdir. İslam medeniyetinden etkilenen Türkler sağlık yapılarına "ev" anlamına gelen Arapça kökenli "darül” ile iyileşme, kurtulma anlamında kullanılan "şifa" kelimesini birleştirerek; topluma sağlık hizmeti sunulan yapılara "darüşşifa" ismini vermişlerdir. Uzun yıllar Türk toplumuna hizmet veren darüşşifalar tıp biliminin ilerlemesiyle birlikte çağın teknik şartlarına uyum sağlayamamış ve yerini Batılılaşmanın etkisiyle ilk defa 1876'de Ahmet Vefik Paşa tarafından kaleme alınan Lehçe-i Osmani ile dilimize isim olarak Farsçadan geçmiş olan hastanelere bırakmışlardır. Bu çalışmada, Osmanlı sağlık yapılarının, darüşşifalardan hastanelere kadar gelişim ve dönüşüm süreci incelendikten sonra Geç Dönem Osmanlı sağlık yapıları Adana vilayeti özelinde değerlendirilecektir. Çalışma kapsamında literatür taraması gerçekleştirilmiş, konu ile ilgili yazılmış tez ve makaleler incelenmiş, çeşitli kurum ve Osmanlı arşivleri araştırılmış, arşivlerden elde edilen mimari projeler değerlendirilmiştir. Çalışma, geç dönem Osmanlı sağlık yapılarının ihtiyaçlar doğrultusundaki gelişimini ve Adana Vilayetindeki geç dönem hastane yapılarının toplu bir tespitini sunmayı hedeflemektedir.

Anahtar Kelimeler

Osmanlı Devleti, Darüşşifa, Hastane, 19. yüzyıl, Adana Vilayeti

\section{Abstract}

Having adopted an understanding of a social state, the Anatolian Turkish States attached great importance to public health and built their health centres accordingly. The Turks, influenced by Islamic civilization, combined the word 'dar' which stood for 'home' in Arabic, and 'şifa' which meant 'recovery' and 'cure', and gave the name darüşşifa to these institutions providing public health care. After serving the Turkish society for centuries, darüşşifas were not able to adapt to the technical conditions of modern medicine, and were replaced by "hastane"s - a name borrowed from Persian with an Ottoman influence, first coined by Ahmet Vefik Pasha in 1876. In this study, after an investigation of how Ottoman health centres developed and were transformed from "darüşşifa" to "hastane", the health structures of the Late Ottoman Period

* Bu makale Yıldız Teknik Üniversitesi Fen Bilimleri Enstitüsü Mimarlık Anabilim Dalı Rölöve- Restorasyon Programı’nda Prof. Dr. M. Cengiz Can’ın danışmanlığında Nur Umar tarafindan hazırlanmış olan “19. Yüzyılda Adana Vilayetindeki Kamu Yapıları" başlıklı doktora tezinden üretilmiştir.

** Sorumlu Yazar: Nur Umar (Doktor Öğretim Üyesi), Alpaslan Türkeş Bilim ve Teknoloji Üniversitesi, Mimarlık ve Tasarım Fakültesi, Mimarlık Bölümü, Adana, Türkiye. E-posta: numar@adanabtu.edu.tr ORCID: https://orcid.org/0000-0003-0296-3671

*** Fatma Zehra Sarı (Yüksek Lisans Öğrencisi), Alpaslan Türkeş Bilim ve Teknoloji Üniversitesi, Mimarlık ve Tasarım Fakültesi, Mimarlık Bölümü, Adana, Türkiye, E-posta: fzehra22@gmail.com ORCID: https://orcid.org/0000-0002-0620-5598

Atıf: Umar, Nur ve Sari, Fatma Zehra. "Geç Dönem Osmanlı Sağıık Yapılarının Gelişiminin Adana Vilayeti Örneği Üzerinden İncelenmesi." Art-Sanat, 14(2020): 469-493. https://doi.org/10.26650/artsanat.2020.14.0018 
were evaluated with examples chosen particularly from the province of Adana. Within the scope of the study, architectural projects attained through literature were evaluated, theses and articles written on the subject were examined, and the Ottoman archives were consulted. The study aims to track the progress of Ottoman health institutions with respect to emerging requirements and provide a mass collection identifying late period hospital structures.

Keywords

Ottoman, Darüşşifa, Hospital, $19^{\text {th }}$ century, Adana Province

\section{Extended Summary}

Darüşsifas are health institutions that are related to today's hospitals in terms of their functions. However, they differ in terms of how the needs of these structures were handled by foundations. In darüşşifas, apart from health care, many activities were conducted such as plant cultivation for herbal medicine, or the nutrition of patients and physicians. In addition, the master-apprentice relationship, which constituted the backbone of traditional medical education, was organized at these institutions.

The Seljuk darüşşifas were built as madrasah ${ }^{1}$ plan schemes with iwans-courtyards. In Anatolia, next to the Seljuk darüşşifas, medical madrasahs were built as well. In the darüşsifa foundations constructed in Anatolia, the style of the double madrasah with iwans and courtyards was adopted and developed as a building type in Anatolian Turkish Architecture. This type consists of spaces opening under a riwaq, instead of them directly opening to the courtyard. Vaults, cones and domes were used in the covering systems of Anatolian Seljuk Darussifas. Stone and brick were used as materials.

The Ottoman State continued to use the old Seljuk darüşşifas, adding various extensions to them, and the blueprint madrasah plan scheme with riwaqs-courtyards in its simplest form was implemented for new structures as well. Darüşşifa structures that provided health services to people later failed to meet the requirements of the more recent eras, as their inadequacies began to become evident. Some of the darüşşi$f a$ institutions that were unable to respond to the conditions of the modern era began to serve the mentally ill. The darüşşifas were provided with various extensions in order to help them regain their functionality.

The Ottoman military, which lost its power in the stagnation period, turned its face to the west in order to take precautions against failures. Until this period, which is generally referred to as Westernization, the Ottoman darüşşifas had maintained their traditional forms consisting of rooms arranged around a central courtyard which evoke the plans of madrasahs. The first innovations in the field of health in the Ottoman Empire were realized after 1789 in Selim III's reign. These innovations were first implemented in the army, parallel to new military arrangements, and started to be applied to general public health as well during Abdulmejid's reign.

1 Moslem Theological School 
Military hospitals, which make up the first examples of innovation in the field of health, were set up using the barracks plan scheme, and they formed a bridge between the first modern hospitals built for civilians and the darüşşifa. These buildings were constructed with a barracks plan scheme representing the military order. In the first civilian hospitals which began to be constructed after some military hospitals, instead of open riwaqs, passages were provided in the form of closed corridors just like those in military barrack plans. In line with the health conditions of the period (in which epidemic diseases were rife), hospitals with independent units were built and these were later connected via enclosed ports to enable easier access throughout the complex. Although the innovations brought into the health institutions of the Ottoman Empire were first seen in the capital and its environs, in line with increasing needs (caused by epidemics, war, internal conflicts, etc.), they started to be implemented in Anatolia as well. These developments in health structures in the capital and the provinces formed the basis of the hospitals of the Republican period.

This study, which we have called "The Development of Late Ottoman Health Structures and Their Investigation through the Example of Adana Province", contains a comprehensive examination of the historical development of Ottoman health institutions in the capital city (Istanbul), showing their locations, construction dates, plans, architectural features, and the way they altered over time. The study proceeds with a detailed examination of the health structures identified in the province of Adana, which grew in significance in the Ottoman Empire in the $19^{\text {th }}$ century. In line with this, the study was completed in three main stages. In the first stage, architectural projects of the Ottoman health buildings found in literature were evaluated, theses and articles written on the subject were examined, Ottoman archives were delved into, and the literature was searched through. In the second stage of the study, health institutions identified in Adana province were examined on-site and detailed descriptions were drawn up. In the third stage, the health foundations of Adana province were evaluated in a more general way.

Within the scope of the study, 7 health structures were identified in Adana province, including its centre and sanjaks. 3 of the 7 detected structures have survived to the present day while 4 of them have not. The structures that have survived to the present day are the Mersin Millet Hospital, Silifke Gureba Hospital and the Kozan Old Hospital, and detailed on-site analyses are concentrated on these three buildings. The Adana Gureba Hospital, Tarsus Gureba Hospital, Hamidiye (Ceyhan) Gureba Hospital and the Adana Municipality Hospital, on the other hand, have not survived to the present day. These structures are documented mostly by archival research. Due to requirements of expansion in health structures and inadequacy of old buildings for new equipment, new structures had to be built. And as the old structures in hospital complexes lost their function, they could not be preserved. 
The study also briefly examines the evolution of health institutions in the Ottoman state which developed in $19^{\text {th }}$ century and tracks the traces of these structures in the Adana province. The main aim of this study was to make a contribution to literature in the fields of architectural history and conservation. 


\section{Giriş}

Darüşşifalar fonksiyon bakımından günümüz hastaneleri ve tıp eğitim merkezlerinin karşıllı̆̆ıdır. "Anadolu'da 'darüşşifa' 'şifahane', 'maristan', 'bimaristan', 'darüssıhha', 'darülâfiye', 'me'menülistirahe', 'darüttıp' isimleri kullanılmıştı..” Darüşşifaların asıl amacı halkın sağlığ i için çalışmak olduğundan darüşşifalarda din, dil, ırk farkı gözetmeden tedavi uygulanmıştır. Şifahane yapıları genellikle külliyeler içerisinde inşa edilmiştir. Bu durum, uygulanan bakım işlerini kolaylaştırmasının yanı sıra, hastaların toplumdan uzaklaşmış hissetmelerini engellemiştir. Darüşşifalar yoksullara, yolculara ücretsiz hizmet etmesi, giderlerinin vakıflar tarafından karşılanması yönleriyle bugünkü hastaneden farklıdır. Psikolojik rahatsızlıkları bulunan hastalara ruhsal tedavi metotları da uygulanmış, hatta bu durum vakfiyelerde açık bir şekilde belirtilmiştir.

İlk defa medrese eğitiminin Büyük Selçuklu Veziri Nizâmülmülk tarafindan sistemleştirilmesiyle medrese plan şemaları oluşmaya başlamıştır. Bu şema aynı zamanda Anadolu'da Selçuklu ve Osmanlı darüşşifa planı olarak uygulanmıştır. Anadolu'da inşa edilen darüşşifa yapılarında eyvanl1-avlulu çifte medrese şeması uygulanıp Anadolu Türk mimarisinde bir yapı tipi olarak gelişmiştir.

Selçuklu darüşşifalarında hem tek blok hâlinde medrese plan şeması hem de çifte medrese plan şeması uygulanmıştır. Osmanlılar ise Selçuklu darüşşifalarını devralıp çeşitli eklemeler yaparak kullanmaya devam etmiş ve yeni inşa ettiği darüşşifalarda da en basit hâliyle revaklı-avlulu medrese plan şemasını ana hatlarıyla uygulamıştır. Osmanlı Devleti devraldıkları darüşşifaların işlevlerini devam ettirdikleri gibi yeni inşa ettiği darüşşifaları da vakıflara bağlayarak devamlılığını sağlamışlardır.

Osmanlı darüşşifaları, medrese planlarını çağrıştıran orta avlu çevresine dizili odalardan oluşan geleneksel formlarını Batılaşma Dönemine kadar sürdürmüşlerdir. Osmanlı sağlık konusundaki ilk yeniliklerini 1789 'dan itibaren askeri düzenlemeler sebebi ile ordu içerisinde gerçekleştirmiş, Tanzimat Dönemi'yle birlikte genel halk sağlı̆̆ uygulamalarında yeniliklerin etkisi hissedilmiştir.

Bu çalışma kapsamında Osmanlı devletinin sağlık alanındaki yenilikleri bütüncül olarak incelenmiş ve Adana vilayeti örnekleri ile detaylı bir şekilde anlatılmaya çalışılmıştır. Araştırma yöntemi olarak; konu ile ilgili yazılmış tez, makale ve kitaplar incelenmiş ve Osmanlı arşivleri araştırılmıştır. Söz konusu yapılar; plan şeması, cephe düzeni, yapım tekniği, mimari üslup ve koruma sorunları bakımından değerlendirilmiştir. Çalışma verilerinin diğer araştırmacılara kaynak oluşturması ve mimarlık tarihi ile koruma alanlarında literatüre katkı sunması amaçlanmıştır.

2 Gönül Cantay, Anadolu Selçuklu ve Osmanlı Darüşşifaları (Ankara: Atatürk Kültür Merkezi Yayınları, 2014), 7 . 


\section{Osmanlı'da Sağlık Yapıları}

\section{Osmanlı Darüşşifaları}

Darüşşifalar genel anlamıyla "insanların sağlık hizmeti aldığı yer" olarak tanımlanabilir. Osmanlı Devleti umumiyetle kervan yolları üzerindeki şehirlerde bulunan Anadolu Selçuklu darüşşifalarından yararlanırken, diğer taraftan da gelişmesi paralelinde kendi sağlık yapılarını eklemiştir. ${ }^{3}$ Osmanlı, Bursa’yı başkent yaptıktan sonra içinde darüşşifa yapısı da bulunan Yıldırım Külliyesi’ni inşa ettirmiştir. Külliye içinde yer alan Yıldırım Darüşşifası, dikdörtgen avluyu üç yönde çevreleyen revakları, revakların arkasında sıralanmış bağımsız mekânları içeren plan şeması ve dış hatlarıyla Anadolu Selçuklu darüşşifalarının yapısını anımsatmaktadır. ${ }^{4}$ Osmanlı Devleti İstanbul'u başkent yaptıktan sonra kentin ihtiyaçlarını karşılamak için, içerisinde bir darüşşifası da bulunan Fatih Külliyesi'ni inşa etmiştir. Fatih Darüşşifanın restitüsyonu için hazırlanan plandan, yapının kare avluyu çeviren revaklarının olması bakımından ana hatlarıyla Yıldırım Darüşşifasının plan şemasını devam ettirdiği görülse de dershane kısmının beşgen çıkmasıyla bu plandan farklılaştığı anlaşılmaktadır. ${ }^{5}$ Edirne, Osmanlı Devleti’nin ikinci başkenti olmasına rağmen İstanbul'daki darüşşifadan sonra burada, II. Bayezid Külliyesi içinde darüşşifa inşa edilmiştir. Bu yapıda ilk kez merkezî plan şeması uygulanmış ve geçiş mekânı bir kubbe ile örtülmüştür. Yap1 dış çerçevesiyle altıgen merkezî kubbeli mekânla bağlantılı, sıralı iki avlu etrafında dizilmiş mekânlardan oluşmaktadır. Medrese plan şemasının ana eyvanın çokgen hâlinde olduğu düşünülse de çokgen yapı kendi içinde bölümlenmiş ve beşgen olarak yapıdan taşmaktadır. Yapı bu özellikleriyle geleneksel medrese plan şemasından uzaklaşmaktadır. ${ }^{6}$ Osmanlı Devleti, başkentler dışında ilk kez Manisa'da darüşşifa yapısı inşa etmiştir. Bu yapıda avlulu medrese şeması ana hatlarıyla uygulanmıştır. Yapıda, diğer darüşşifalarda olduğu gibi mekânlar bağımsız koğuş şeklindedir. ${ }^{7}$ Edirne'den sonra merkezî planlı darüşşifa yapısı İstanbul Haseki Darüşşifasında uygulanmıştır. Darüşşifa dış hatlarıyla dikdörtgene yakın olsa da merkezî sekizgen bir avluya açılan mekânlardan oluşması ve sokağın köşe durumuna göre şekillenmiş olması yapıyı geleneksel şemadan farklılaştırmıştır.

Klasik Dönem eseri olan Süleymaniye Darüşşifası bahsedilen darüşşifa planlarından farklı olarak kurgulanmıştır. Yapı topografik koşullara uyumlu olarak iki katlı inşa edilmiştir. Bodrum kat dükkânlar ve akıl hastaları için dikdörtgen salon; üst kat aynı yönlü iki avlu ve büyük avlunun revakları arkasındaki mekânlardan oluşmaktadır. İki

3 Nuran Yıldırım, Hastane Tarihimizde Bir Kutup Ylldızı Hamidiye Etfal Hastanesi (İstanbul: Ajansfa, 2010 ), 19.

4 Cantay, Anadolu Selçuklu ve Osmanlı Darüşşifaları, 16.

5 Gönül Cantay, “Osmanlı Mimarisinde Darüşşifalar,” Prof. Dr. Ali Haydar Bayat Anısına Düzenlenen Osmanlı Sağlık Kurumları Sempozyumu Haziran (2007), (İstanbul: Zeytinburnu Belediyesi, 2008), 70.

6 Gönül Cantay, “Darüşşifalar,” Mimar Başı Koca Sinan Yaşadığı Çă̆ ve Eserleri (İstanbul: Vakıflar Genel Müdürlüğü Yayınları, 1988), 1: 355.

7 Cantay, "Darüşşifalar," 356. 
avludan oluşan üst kat, Anadolu Selçuklu çifte medrese planını anımsatmaktadır. XVI. yüzyıl sonlarında inşa edilen külliye içinde planlanan yine topografik şartlara uygun olarak inşa edilen Atik Valide Darüşşifası, iki kademeli ve farklı derinlikli revak sisteminin çevirdiği dikdörtgen avlu etrafındaki mekânlardan oluşmaktadır. Darüşşifanın kendine ait hamamının bulunması temizlik-sağlık ilişkisinin sürekliliği bakımından önemlidir. ${ }^{8}$ Osmanlının son darüşşifası olan Sultan Ahmet Darüşşifası'nın, Prof. Dr. A. Süheyl Ünver'in gözlemiyle oluşturulan Mektebi Sanayi planından yaklaşık olarak elde edilen bir krokisi vardır. Mevcut krokiye göre yapının, kareye yakın dikdörtgen avlu arkasındaki tek sıralı mekânlarla klasik medrese plan şemasını referans aldığ 1 görülmektedir. ${ }^{9}$

Osmanlı'da darüşşifa yapıları genel hatlarıyla Selçuklu dönemi avlulu medrese plan şemasını sürdürmüşlerdir. Ancak yapılar bu devamlılığın dışında dönemlerinin mimari karakterini de yansıtmışlardır. Osmanlı darüşşifaları; tek yapı şeklinde olanlar, çifte medrese planındaki darüşşifalar ve merkezî planlılar olarak gruplandırılabilir. Uygulanan bu plan tiplerinden üçüncüsü Osmanlı Devleti'nde görülen bir uygulamadır. ${ }^{10}$ Osmanlı Dönemi darüşşifaları ana hatlarıyla Selçuklu Dönemi avlulu medrese planlarını devam ettirirken öte yandan gelişimleri doğrultusunda kendi mimari ve plan niteliklerini ortaya koymuşlardır. Osmanlı Dönemi'nde bu yapılar daha işlevsel, daha ince hatlı olarak kendilerini göstermiş̧ir. ${ }^{11}$ Osmanlı Dönemi darüşşifaları dinî yapıya birleşmemesi ve türbe mekânlarının olmamasıyla Selçuklu Dönemi darüşşifalarından farklılaşmıştır. Selçuklu Dönemi darüşşifalarındaki 1sınma problemi, Osmanlı darüşşifalarında ocaklarla çözülmüştür.

Osmanlı Dönemi darüşşifalarında yapı malzemesi olarak genellikle taş ve tuğla kullanmıştır. Klasik döneme kadar darüşşifa yapılarının geneli moloz taş ile inşa edilmiş, Edirne II. Beyazid Darüşşifası'nda yapı malzemesi olarak kesme küfeki taşı seçilmiştir. Klasik Dönem ile birlikte yapılarda kesme taş kullanılmaya başlanmıştır. Yapıların üstü genellikle tuğla kubbelerle örtülmüş olup cephelerinde, dengeli ve süslemesiz sade bir düzen görülmektedir.

\section{Osmanlı'da Darüşşifadan Hastaneye}

Osmanlı darüşşifaları, medrese planlarını çağrıştıran orta avlu etrafına dizilmiş mekânlardan oluşan geleneksel biçimlerini Batılaşma Dönemi'ne dek devam ettirmişlerdir. Osmanlı, sağlık konusundaki ilk yeniliklerini 1789'dan sonra III. Selim

8 Cantay, Anadolu Selçuklu ve Osmanlı Darüşşifaları, 18.

9 Ahmet Vefa Çobanoğlu, "Yok Olan Bir Yapı Sultanahmed Darüşşifası," Sanat Tarihi Araştırmaları Dergisi 2 (1988), 35; Cantay, Anadolu Selçuklu ve Osmanlı Darüşşifaları, 100.

10 Cantay, Anadolu Selçuklu ve Osmanlı Darüşşifaları, 38.

11 Abdullah Kılıç, Anadolu Selçuklu ve Osmanlı Şefkat Abideleri Şifahaneler (İstanbul: Medialpark, 2012), 66-67. 
Dönemi’nde yeni askeri düzenlemeler sebebi ile ordu içerisinde uygulamış, Abdülmecid Dönemi'nde ise genel halk sağlığ 1 olarak yaygınlaştırmıştır. III. Selim'in yeni "Nizam-1 Cedid" ordusunun ihtiyaçlarını karşılamak amacıyla Levent Çiftliği'ndeki askeri kışlaya 1799 yılında "Levent Çiftliği Hastahanesi” adı ile ilk modern Osmanlı sağlık yapısını yaptırdığ 1 ancak bu yapının 1808'de yeniçeriler tarafından yakıldığ1 bilinmektedir. 1808'de Anadolu'dan gelen askerleri eğitmek için Üsküdar-Kadıköy arasına Haydarpaşa civarına içinde bir hastanesi de olan, ilk Selimiye Kışlası yapılmıştır. ${ }^{12}$ III. Selim'in tahtan indirilmesi ile duraklayan sağlık yenilikleri, II. Mahmut Dönemi'nde, 14 Mart 1827'de Şehzadebaşı'nda Tulumbacıbaşı Konağı'nda “'Mektebi Tıbbiye"nin açılmasıyla yeniden başlamıştır. Askerî hastaneler, darüşşifalardan modern hastanelere geçiş yapıları olarak nitelendirilebilir. Bu gelişmelerden on yı1 sonra halkın sağlık ihtiyaçlarının karşılamak amacıyla Edirnekapı Mihrimah Sultan Külliyesi'nin medresesinin "Gureba” adıyla hastaneye dönüştürülmesiyle ilk sivil hastane yapısı görülmüştür.

Genel halk sağlığı ve sivil sağlık kurumları değişimlerini Tanzimat Fermanı'nın ilanından sonra yaşamıştır. Osmanlı Devleti 1831 İstanbul'daki kolera salgını sebebiyle karantina uygulaması yapmak zorunda kalmış ve bu durum darüşşifaların işlevlerinin yetersiz olduğunu ve önlemler alınması gerekliliğini ortaya koymuştur. ${ }^{13} \mathrm{Bu}$ zorunluluk, dolaşımın açık revaklarla sağlandığı darüşşifalar yerine, kapalı koridorlara açılan koğuşlar şeklinde yeni bir plan şemasını meydana getirmiştir. Kışla plan şemasını tekrarlayan, koğuşların aynı kapalı koridora açıldığı Bezm-i Alem Valide Sultan Gureba Hastanesi' yle ise bir sonraki aşamaya taşınmıştır. Kırım Savaşı esnasında 1854'te Selimiye Kışlası'nın bir bölümü hastaneye dönüştürülmüştür. 1875 yılında yapımına başlanan Osmanlı Devleti'nin modern sağlık kurumlarına örnek olabilecek nitelikte, Yusuf Kamil Paşa'nın ölümünden sonra eşi Zeynep Sultan tarafından yapımına devam edilen Zeynep Kamil Hastanesi, 1882 yılında tamamlanmıştır. ${ }^{14}$ Osmanlı Devleti'nin ilk modern hastaneleri sayılan bu yapılar değişim ve dönüşümün sağlık alanındaki örnekleri olmuştur.

\section{Geç Dönem Osmanlı Hastaneleri}

Osmanlı Devleti'nin sağlık alanındaki modernleşmesinin başlangıcı olan askerî hastaneler, darüşşifalardan modern hastanelere geçiş arasında köprü niteliğindedir. Söz konusu bu modernleşme döneminde, halkın sağlık ihtiyaçlarını karşılamak amacıyla işlevini kaybetmiş darüşşifaların (akıl hastanesi-hapishane vb. yapılara çevrilmiş) sağlık koşulları iyileştirilmeye çalışılmış ya da bazı yapılara yeniden işlev verilerek hastaneye dönüştürülmüştür.

12 Yıldırım Yavuz, "Batılaşma Döneminde Osmanlı Sağlık Kuruluşları," ODTÜ Mimarlık Fakültesi Dergisi 8/2 (1988), 124.

13 Gülden Sarıyıldız, "Karantina,” TDV İslam Ansiklopedisi, c. 24 (İstanbul: Türkiye Diyanet Vakfı Yayınları, 2001), 463.

14 Bahar Demirhan, “Zeynep Kâmil Hastahanesi Restorasyon Projesi” (Yüksek Lisans tezi, İstanbul Teknik Üniversitesi, 2005), 28-29. 
Osmanlı Devleti'nin ilk hastane yapıları, askerî 1slahatlar paralelinde gelişen kışla plan tipli hastanelerdir. Haydarpaşa Askerî Hastahanesi'nde darüşşifalardaki açık revaklar yerini kapalı koridorlara bırakmış olup aynı koridora açılan koğuşlar dönemin sağlık koşullarına (salgın hastalıklar tifo-kolera) ters düşmüştür. ${ }^{15}$ Dönemin öncü tıp okulu Mekteb-i Tıbbiye-i Şahane'de ise kışla planı uygulanmış ve okul günümüz eğitim yapılarının planlarından farklı bir anlayışla tasarlanmıştır. Haydarpaşa Askerî Hastanesi ve Mekteb-i Tıbbiye-i Şahane’nin yetersizlikleri göz önüne alınarak, dönemin sağlık koşularının gerektirdiği pavyon sistemi ve kışla şeması birleştirilerek dönem için en uygun çözüm Haydarpaşa Numune Hastanesi'nde uygulanmıştır. Açık revaklarla dolaşımın sağlandığı geleneksel darüşşifalara göre kapalı koridorlara geçiş aşaması olarak nitelendirilebilecek ilk sivil hastane olarak inşa edilen Bezm-i Alem Vakıf Gureba Hastanesi'nde kışla planı, yetersizliklerine rağmen yinelenmiştir. Hastaneler; hastaları iyileştirmenin beraberinde tıbbı bilgilerin arttırılması ve geliştirmesinde gerekli birimler olarak görülmüş; gelişimlerine önem verilmiştir. Dönemin salgın hastalıkları yüzünden tamamen birbirinden bağımsız pavyon tipi hastaneler yapılmıştır. Bulaşıcı hastalıklar yönünden ayrı pavyonların inşâsı olumlu bir çözüm olmasına rağmen servis ve ulaşımların açık havadan yapılması bu çözümün işlerliğini azaltmıştır. Bu plan tipi Hamidiye Etfal Hastanesi ve Haseki Nisa Hastanesi'nde görülmektedir. Zeynep Kamil Hastanesi’nde ise geleneksel darüşşifalar ve askerî hastanelerde görülen iç avlulu plan şeması yerine "U" şeklinde bir plan şeması uygulanmıştır. Batılılaşma Dönemi’yle başlayan bu değişim sürecinde, geleneksel sağlık kurumlarının plan şemaları farklılaşarak modern plan şemalarını meydana getirmiştir. Bu süreçte üretilen sağlık yapıları yeni kurulan Cumhuriyet Dönemi modern hastanelerinin temelini oluşturmuştur.

Osmanlı Devleti'nin ilk modern hastaneleri söz konusu plan şemaları bağlamında incelediğinde Haydarpaşa Askerî Hastahanesi ve Mekteb-i Tıbbiye-i Şahane Hastahanesi'nin kışla plan şemasıyla inşa edildiği anlaşılmaktadır. Kitabesine göre 1845 yılında inşa edildiği anlaşılan Haydarpaşa Askeri Hastahanesi, dikdörtgen şeklinde olup ortası avluludur. Yapının köşe kısımları ve kuzey cephesinin orta kısmı d1şarı doğru çıkıntılıdır. Dikdörtgen formlu orta avluyu iki katta saran kapalı koridorlar üstünde sıralı büyük mekânlardan meydana gelen plan şemasına sahiptir. Neoklasik üsluba sahip yapının giriş bölümü iki katlı olup dışarı taşmıştır. Yapı yığma kâgir tekniğiyle inşa edilmiş ve kat döşemelerinde ahşap kirişleme tekniği kullanılmıştır. ${ }^{16}$ Diğer bir kışla plan şemasını anımsatan ve Haydarpaşa Askeri Hastanesi yakınına inşa edilen Mekteb-i Tıbbiye-i Şahane devrin öncü mimarlarından Alexandre Vallaury ve Raimondo D'Aronco'ya tasarlatılmıştır. Yapı, deniz tarafinda beş, cadde tarafında üç katlı, doğu-batı yönündeki orta eksene göre simetrik olarak planlanmış olup aynı

15 Yavuz, "Batılaşma Döneminde Osmanlı Sağlık Kuruluşları,” 126-127.

16 Aynur Çiftçi, “19. Yüzyılda Osmanlı Devleti’nde Askeri Mimari ve İstanbul'da İnşa Edilen Askeri Yapılar” (Doktora tezi, Yıldız Teknik Üniversitesi, 2004), 203. 
doğrultu üzerine cadde ve deniz tarafindan iki ana girişe sahiptir. Yap1 yığma kâgir yapım sistemi ile inşa edilmiştir. Döşeme, demir - tuğla karışımı volta sistemi; çatı strüktürü, pencere doğramaları ve merdivenleri demirle inşa edilen okulun cephesi oryantalist üslubun belirgin olduğu seçmeci bir anlayışla biçimlendirilmiştir. Yapının cepheleri taşla kaplanmış, bazı bölümlerde sivri veya yassılaşmış kemerler geniş saçaklar, minare görünümlü soğan kubbeli kuleler kullanılmıştır. ${ }^{17}$

İstanbul'daki sağlık kurumlarının yetersiz kalması ile halk sağlı̆ğın korumak amacıyla Edirnekapı Mihrimah Sultan Külliyesi içinde bulunan ve darüşşifa plan şemasına benzeyen medrese yapısı "Gureba" adıyla ilk sivil hastane olarak kullanılmaya başlanmıştır. ${ }^{18}$ Sivil halk için inşa edilen ve "Gureba" hastanelerinin en tanınmışı olan Bezm-i Âlem Vakıf Gureba Hastanesi, açık revaklarla dolaşımın sağlandığ 1 geleneksel darüşşifalara göre kapalı koridorlara geçiş aşaması olarak değerlendirilebilir. Dikdörtgen iç bahçeyi çevreleyen kapalı koridorların dış taraflara sıralı hasta koğuşlarından oluşan geleneksel Osmanlı medreseleri ile örtüşmektedir. Yapı çoğunlukla tek katlı olup kuzey ve doğu tarafındaki cephelerin alt tarafına arazinin topografik avantajı sayesinde bodrum kat da inşa edilmiştir. Orta aksına göre simetrik olan yapı, tuğla duvarlı, kiremit kaplı kırma ahşap çatılıdır. Eş aralıklı tek tip taş söveli düşey penceresi olan yapının ana girişi, yapıya göre daha yüksek olan beşik çatısıyla ön plana çıkarılmıştır. Girişin önündeki kapalı revak, çift simetrik dairesel sütün üzerine yerleştirilen ahşap alınlıkla 'neoklasik' üslubu çağrıştırmaktadır. ${ }^{19}$

Pavyon tipi plan şeması, dolaşım ve servis zorluklarına rağmen salgın hastal1klara önlem için en iyi çözüm olarak kabul edilmiştir. Osmanlı Devleti'nde bu sistemle inşa edilmiş olan ilk hastane yapısı 1899'da tamamlanan Hamidiye Etfal Hastanesi'dir. Osmanlı Devleti'nin ilk çocuk hastanesi olan yapının ana girişi batıda olup toplam on ayrı pavyondan oluşmaktadır. ${ }^{20}$ Hastanenin önce art arda simetrik olarak konumlandırılmış dört çift küçük pavyon, ön hizada ve ortada bulunan bir yönetim yapısı ve arkada küçük bir 1sı merkeziyle inşa edildiği bilinmektedir. Bahçe kapısının karşısındaki üç yapının merkezinde yer alan iki katlı merkez binasının iki büyük kulesi vardır. Pavyonların yer aldığı alanın tam ortasındaki bahçenin merkezine yapılan cami ile saat kulesi bulunmaktadır. Simetrik dört çift pavyonların dar olan doğu ve batı cephelerinde birer kapıyla girilen giriş mekânları bulunmakta, hastane üçer pencereli on ikişer yataklı koğuş mekânlarından oluşmaktadır. Hasta koğuşları kuzey cephedeki kare çıkmaya açılmıştır. Taşıyıcı tuğla duvar ve demir volta döşeme tekniği ile yapılan üzeri kiremit kaplı ahşap çatılarla örtülü genel ola-

17 Yavuz, "Batılaşma Döneminde Osmanlı Sağlık Kuruluşları," 133.

18 Nuran Yıldırım, Tarihi Sağlık Kurumlarımız Darüşşifalar (İstanbul: Ajansfa, 2010), 2:141; Seçil Mursal, "Osmanlı Devleti’nde İlk Guraba Hastaneleri" (Yüksek Lisans tezi, Cumhuriyet Üniversitesi, 2017), 5.

19 Yavuz, "Batılaşma Döneminde Osmanlı Sağlık Kuruluşları," 126.

20 Nuran Yıldırım, Hastane Tarihimizde Bir Kutup Yıldızı Hamidiye Etfal Hastanesi, 38. 
rak tek katlı pavyonların ölçüleri küçük ve ölçekleri çocuk boyutlarına uygundur. ${ }^{21}$ Hastanenin mescidi ve mescitten taşırılmış saat kulesinde oryantalist motifler içeren sade bir kompozisyon görülmektedir. Dönem kaynaklarında yapı için; style Turc (Türk üslubu) terimi kullanılmıştır. ${ }^{22}$

Osmanlı Devleti'nin pavyon tipi plan şemasına sahip hastane yapısına Haseki Nisa Hastanesi de örnek verilebilir. Çağlarının gerisinde kalmış olan darüşşifalar zamanla işlevlerini yerine getiremez hâle gelmiştir. Kadın mahkûmların kaldığı bir yer hâline dönüşen Haseki Darüşşifası, mahkûmların nakledilmesi ile köhneleşmiştir. Dönemin sağlık kuruluşlarında uygulanan pavyon sistemi ile yeni bir yapı inşa edilerek Haseki Darüşşifası'nın adı yaşatılmıştır. ${ }^{23}$ Ahşap olarak inşa edilen pavyonlar işlevlerine göre 3 farklı boyutta planlanmıştır. Hastaneye 1911 yılında betonarme cerrahi pavyonu eklenerek modern hastaneye dönüşümü tamamlanmıştır. Hastanenin özellikle idari binasının cephesinden devrin üslubu "Türk neoklasiği” nin uygulandığg düşünülebilir.

Osmanlı Devleti'nde sağlık yapılarının modernleşmesi döneminde Dr. Rieder tarafindan pavyonların kapalı koridorlarla bağlandığı plan şemasına sahip Haydarpaşa Numune Hastanesi yapılmıştır. ${ }^{24}$ Mekteb-i Tıbbiye'ye bağlı hastane, yapının asıl girişi aksında Tıbbiye Caddesi'nin karşı kenarında büyük dikdörtgen avluyu saran kapalı koridorlara sadece birer dar kenarlarından bağlanan simetrik olarak konumlandırılmış iki katlı on iki pavyon ve başka gerekli servis yapılarından oluşmaktadır. Osmanlı Devleti'nin ilk sivil hastane örneklerinden olan Bezm-i Âlem Guraba Hastanesi'nde görülen askerî kışlalarından etkilenmiş kapalı koridor sistemiyle Hamidiye Etfal'de görülen bağımsız pavyon sistemini karışımı şeklindeki çözümü ile çağa en uygun plan şeması uygulanmıştır. Bu sistem açık havadaki ulaşıma gerek kalmadan pavyonlar arasında yeterince ayrım yapılmıştır. Çamaşırlık gibi servis hizmetleri pavyonlar arası yapıyı dışardan çevreleyen dekovil ${ }^{25}$ yoluyla iç dolaşım birbirinden ayrılmıştır. Maddi yetersizliklerden dolayı planlanan bu şemanın üç pavyonu yapılabilmiş; çağdaş tıp anlayışına uyum sağlayan plan kâğıt üzerinde kalmıştır. ${ }^{26}$ Dış cepheleri iki renkli hereke taşından yontma olarak Neoklasik üslupta inşa edilmiştir.

Pavyonların kapalı koridorlarla bağlandığı plan şeması ve kışla plan şeması ile darüşşifa plan şemasının bütünleştiği iç avluyu ' $U$ ' şeklinde çevreleyen plan şeması-

21 Gönül Güreşsever Cantay, "XIX. Yüzyılda Kurumlaşma ve Hastahaneler II”, FSM İlmi Araştırmalar İnsan ve Toplum Bilimleri Dergisi 2, Güz (2013), 65.

22 Çağrı Güntan, "II. Abdülhamit Döneminde İmparatorluk İmajının Kamu Yapıları Aracılığı İle Osmanlı Kentine Yansıtılması" (Yüksek Lisans tezi, Yıldız Teknik Üniversitesi, 2007), 127.

23 Gülhan Balsoy, "Bir Kadın Hastanesi Olarak Haseki Hastanesi ve 19. Yüzyıl İstanbul'unda Bikes ve Bimesken Bir Kadın Olmak,” Toplumsal Tarih Dergisi 257 (Mayıs 2015), 81-82.

24 Yavuz, "Batılaşma Döneminde Osmanlı Sağlık Kuruluşları," 132.

25 Raylarının aralığg $60 \mathrm{~cm}$ ya da daha az olan, arabaları buhar, insan ya da hayvan gücüyle yürütülen, küçük demiryolu. "Dekovil," erişim 08 Aralık 2019, https://sozluk.gov.tr/?kelime=DEKOV\%C4\%B0L

26 Yavuz, "Batılaşma Döneminde Osmanlı Sağlık Kuruluşları,” 136. 
na sahip Osmanlı Devleti'nin ilk modern hastanelerinden Zeynep Kâmil Hastanesi, Üsküdar Nuhkuyusu'nda Yusuf Kamil Paşa ve eşi Zeynep Sultan tarafından yaptırılmıştır. Yı̆̆ma yapım sistemiyle yapılan yapı, bodrum kat ve 2 kattan oluşmaktadır. Kendine ait bir cami veya mescidin bulunmaması geleneksel sağlık yapılardan yapıyı ayırmıştır. Yapı, zemin ve üst katta simetrik olarak sıralanmış farklı işlevlerde kullanılan birçok mekândan ve bu mekânlara ulaşımı sağlayan iki doğrusal koridordan oluşmaktadır. Neoklasik üslubun ön planda olduğu yapıda dikdörtgen pencereler her katta aynı düşey eksene yerleştirilerek simetrik cephe düzeni görülmüştür. Dönemin mimarlık anlayışında kullanılan kat aralarında ve saçak doğrultusunda yerleştirilen kornişler cephenin yatay elamanları olmuştur. ${ }^{27}$

Batılılaşma dönemiyle yapılarda yeni bir şekillenme süreci başlamıştır. Bu yeni oluşumlar ihtiyaçlara karşılık verebilecek şekilde sağlık yapılarında da kendini göstermiştir. Tanzimat Dönemi'nden sonra halka hizmet vermek için öncelikle Gureba hastaneleri açılmaya başlanmıştır. II. Abdülhamit Dönemi’nde Hamidiye Hastaneleri olarak, daha sonralarda ise Millet Hastanesi, Belediye Hastanesi vb. isimlerde karşımıza çıkmaktadır. Osmanlı Devleti'nin başkenti başta olmak üzere Anadolu'nun kentlerinde de gureba hastaneleri hizmet vermeye başlamıştır. Çalışmanın özgün kısmında yer alan Adana Gureba Hastanesi başta olmak üzere Ankara, Antalya, Aydın, Bursa, Edirne, Erzurum, Konya, Manisa gibi önemli Anadolu kentlerinde de gureba hastaneleri inşa edilmiştir. Çalışmanın devamında Adana vilayetinde Osmanlı'nın son döneminde inşa edildiği tespit edilen hastane yapıları ele alınmaktadır.

27 Bahar Demirhan, "Zeynep Kâmil Hastahanesi Restorasyon Projesi,” 74. 


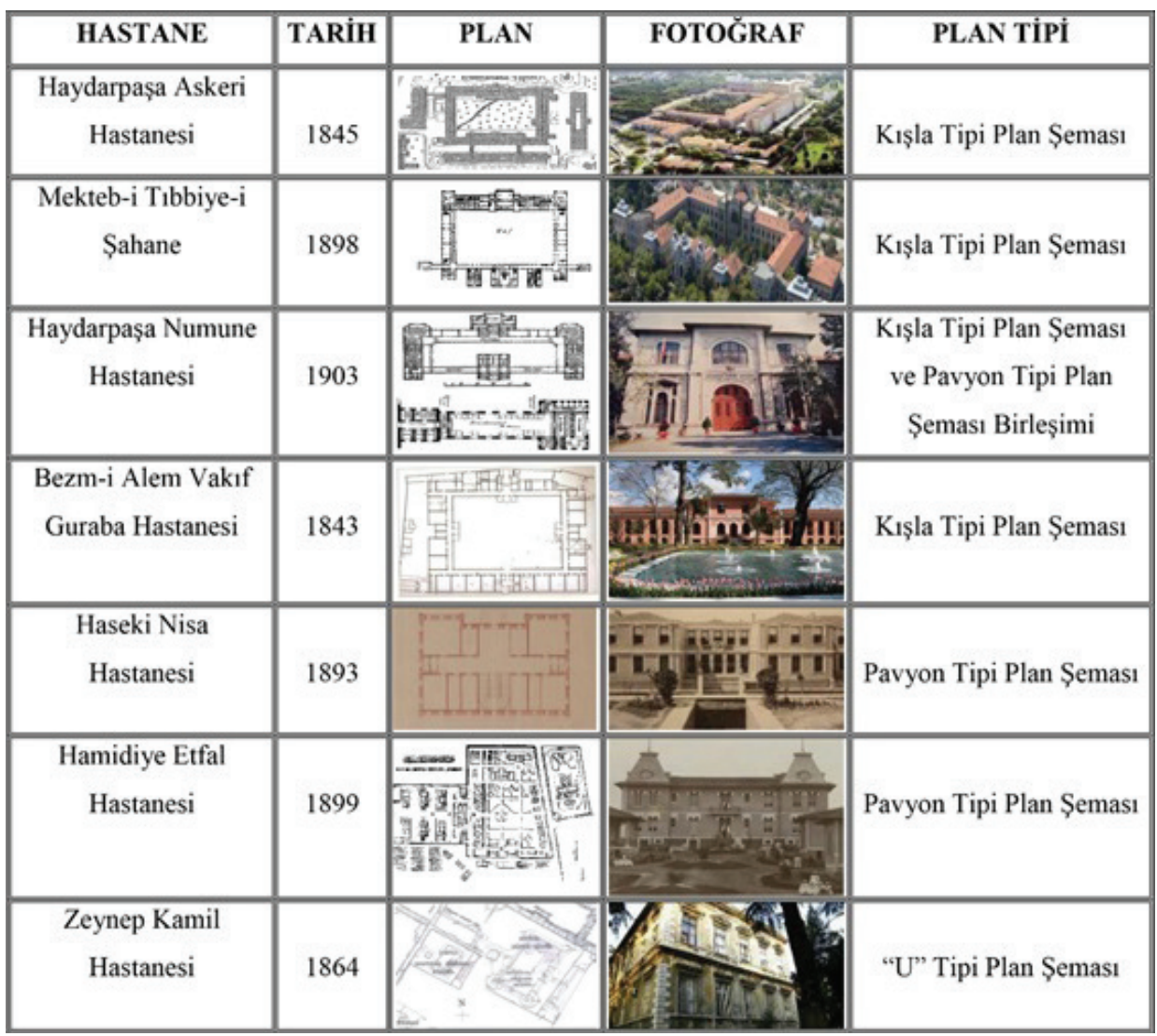

G. 1. Osmanlı Dönemi İstanbul Hastaneleri ${ }^{28}$

\section{Osmanlı’nın Son Döneminde Adana Vilayetindeki Hastane Yapıları}

Adana vilayeti, 1869 yılında idari olarak kurulmuş ancak yeni sancakların eklenmesiyle zaman içerisinde sınırları değişmiştir. Vilayet hududunun en geniş olduğu 18881922 yıllarındaki sınırlar, araştırma için geçerli kabul edilmiştir. Bu dönemde Adana vilayeti; “Adana Sancağı", “Cebel-i Bereket Sancağı”, “Kozan Sancağı”, "Mersin

28 Planlar sırasıyla, Çiftçi, “19. Yüzyılda Osmanlı Devleti’nde Askeri Mimari ve İstanbul’da İnşa Edilen Askeri Yapılar” (Doktora tezi, Yıldız Teknik Üniversitesi, 2004), Cilt II-202; Yavuz, "Batılaşma Döneminde Osmanlı Sağlık Kuruluşları”, 132; Yavuz, "Batılaşma Döneminde Osmanlı Sağlık Kuruluşları”, 135-136; Güreşsever Cantay, "XIX. Yüzyılda Kurumlaşma ve Hastahaneler I” 125, http://haritalar.istanbul.edu.tr/ viewer.php?tileCode=92617; Yavuz, "Batılaşma Döneminde Osmanlı Sağlık Kuruluşları", 128; Ekter, Günergun "Zeynep-Kamil Hastanesi (1875): Romantik Tarihçiliğin Gölgesinden Bir Çıkış Denemesi”, Prof. Dr. Ali Haydar Bayat Anısına Düzenlenen Osmanlı Sağlık Kurumları Sempozyumu, 159; yapı fotoğrafları sirasiyla, https:/www.facebook.com/abdulhamideah/, https:/www.emlaklobisi.com/bilgi-bankasi/ haydarpasa-numune-egitim-ve-arastirma hastanesi-90444, http://abdulhamid.site/abdulhamid-ve-eserleri/ abdulhamid-donemi-hastaneler/haydarpasa-numunehastanesi/, http://bezmialem.edu.tr; Balsoy "Bir Kadın Hastanesi Olarak Haseki Hastanesi ve 19. Yüzyıl İstanbul'unda Bikes ve Bimesken Bir Kadın Olmak”, 81; Yıldırım, Hastane Tarihimizde Bir Kutup Yıldızı Hamidiye Etfal Hastanesi, 41; https://zeynepkamilkdch. saglik.gov.tr/TR,87631/tarihcemiz.html. 
Sancağı", "İçel(İçil) Sancağı" olmak üzere 5 sancak ve 20 kazadan oluşmaktadır. Günümüzde bu sancak ve kazalar, Adana, Mersin, Karaman, Osmaniye, Hatay ve Gaziantep illerinin sınırları içerisinde yer almaktadır. Adana vilayetindeki sağlık yapıları; salgın hastalıkları önlemek ve halk sağlığını korumak amacıyla bir yapı türü olarak ortaya çıkan hastane yapılarından oluşmaktadır. Modern anlamda ilk bilinen hastane yapıs1 1893 yılında inşa edilmiş olup, Cumhuriyetin ilk dönemine kadar 7 hastane yapılmıştır. Yapıldı̆̆ı tespit edilen hastanelerin sancaklara göre dağılımı aşağıdaki haritada görülmektedir.

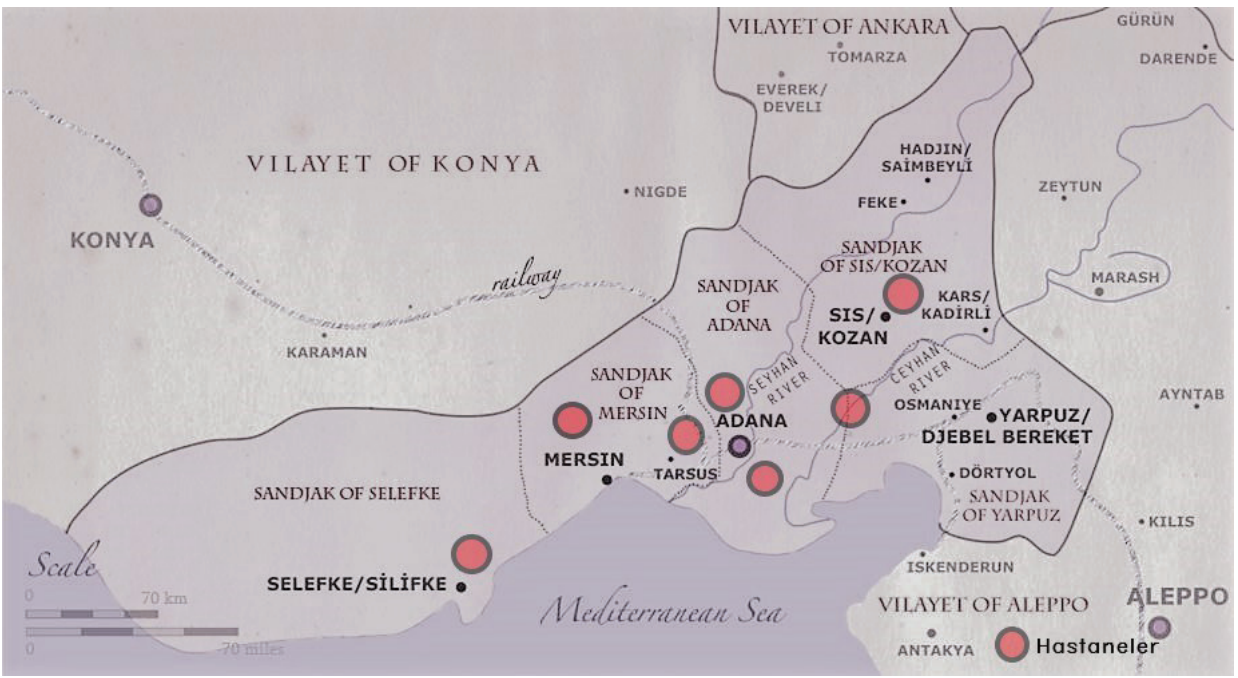

G. 2. Adana Vilayetinde 1869-1922 y1lları arasında yapıldığ 1 tespit edilen hastanelerin dağılımı $1^{29}$

\section{Adana Gureba Hastanesi}

1896-97 yıllarında Adana Gureba Hastanesi adıyla Seyhan Nehri’nin doğu yakasında inşa edilmiş olup sonradan ismi Devlet Hastanesi olarak değiş̧irilmiştir. Başbakanlık Osmanlı Arşivinde yer alan 14.04.1898 tarihli Adana'dan çekilen telgraf belgesinde, Gureba Hastanesinin Adana'da Seyhan Nehri kenarına inşa edildiği ve Padişah'ın ismi ile adlandırılması istendiği yazmaktadır ${ }^{30}$. O dönemde yayınlanan 342 numaralı Servet-i Fünun dergisinde yer alan fotoğrafından anlaşıldığ 1 üzere hastane üç pavyondan oluşmaktadır (G. 3). Pavyonlar tek katlı ve dikdörtgen planlıdır. Eyvanlı giriş kısımları ve pencereleri dairesel kemerlidir. Yalnızca ortadaki pavyonun üstünde cihannüma benzeri bir kat yer almakta, önünde ise küçük bir balkon bulunmaktadır. Yapılar kesme taştan yı̆̆ma yapım sistemi ile inşa edilmiştir. Yapıların ne zaman yıkıldığı tespit edilememekle birlikte, bulunduğu yerdeki hastane kompleksi 2010'lu yıllara kadar hizmet vermiştir.

29 https://www.houshamadyan.org web sitesinden alınan harita üzerinden hastanelerin dağılımı gösterilmiştir.

30 Başbakanlık Osmanlı Arşivi (BOA), Yıldız Mütenevvi Maruzat (Y..MTV.) 175/317, 23/ Za/1315 (14 Nisan 1898). 


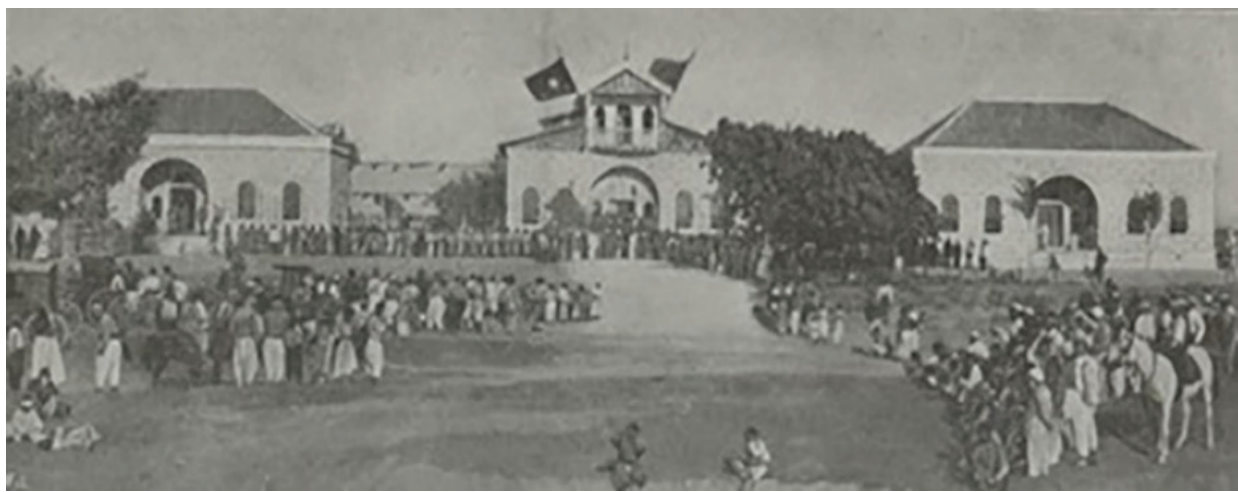

G. 3. Adana Gureba Hastanesi, 18 Eylül 1313 (Servet-i Fünun Dergisi 342, 54)

\section{Mersin Millet Hastanesi}

Mersin ili, Akdeniz ilçesi, Nusratiye Mahallesi'nde yer alan yapının inşaatına 1907 yılında başlanmış, Belediyenin ve halkın desteği ile 1908 yılında tamamlanarak 40 yataklı olarak hizmete girmiştir ${ }^{31}$.

Yapının 1910 yılına ait fotoğraflarından anlaşıldığı üzere; yapı dikdörtgen planlı, bodrum + iki katlı ve kırma çatılıdır. Sağ ve sol köşeleri dışa taşırılarak cephe hareketlendirilmiştir. Pencereleri dikdörtgen formda düz atkılı ve sövelidir. Yan cephesinde yer alan balkon çıkmaları çokgen formunda biçimlendirilmiştir. 1923 yılında, zührevi hastalıklar için bir pavyon, 1930 yılında verem pavyonu, 1938 yılında kadın doğum bölümü eklenmiştir. İşgal yıllarında ismi Belediye Hastanesi, sonrasında ise Memleket Hastanesi ve Devlet Hastanesi olarak değişmiştir. İlk hastane yapısı günümüze kadar ayakta kalmış olup günümüzde Mersin Kamu Hastaneleri Birliği Genel Sekreterliği olarak kullanılmaktadır. Yapının çevresine eklenen yeni binalarla genişletilen hastane, kompleks şeklinde hizmete devam etmektedir.

Günümüzde yerinde yapılan tespitlerde; özgün yapının onarım geçirmiş olduğu, dış cephesinin boyandığı, doğramalarının PVC, ana giriş kapısının metal ile değiştirildiği ve pencere önlerinin demir ferforje korkuluklarla kapatıldığ Yapının ana giriş merdivenlerinin yeniden beton olarak yapılarak, üstü yarım silindir şeklinde bir tente ile kapatıldığ 1 tespit edilmiştir. Cephe düzeni olarak özgünlüğünü büyük oranda korumuş olan yapının cephesinde yer alan iklimlendirme elemanlarının yapının algılanmasına olumsuz etkisi olup görüntü kirliliği oluşturmaktadır.

31 H. Şinasi Develi, Eski Mersinde Yaşam (Mersin: Kırkambar Kitabevi, 2007), 242. 


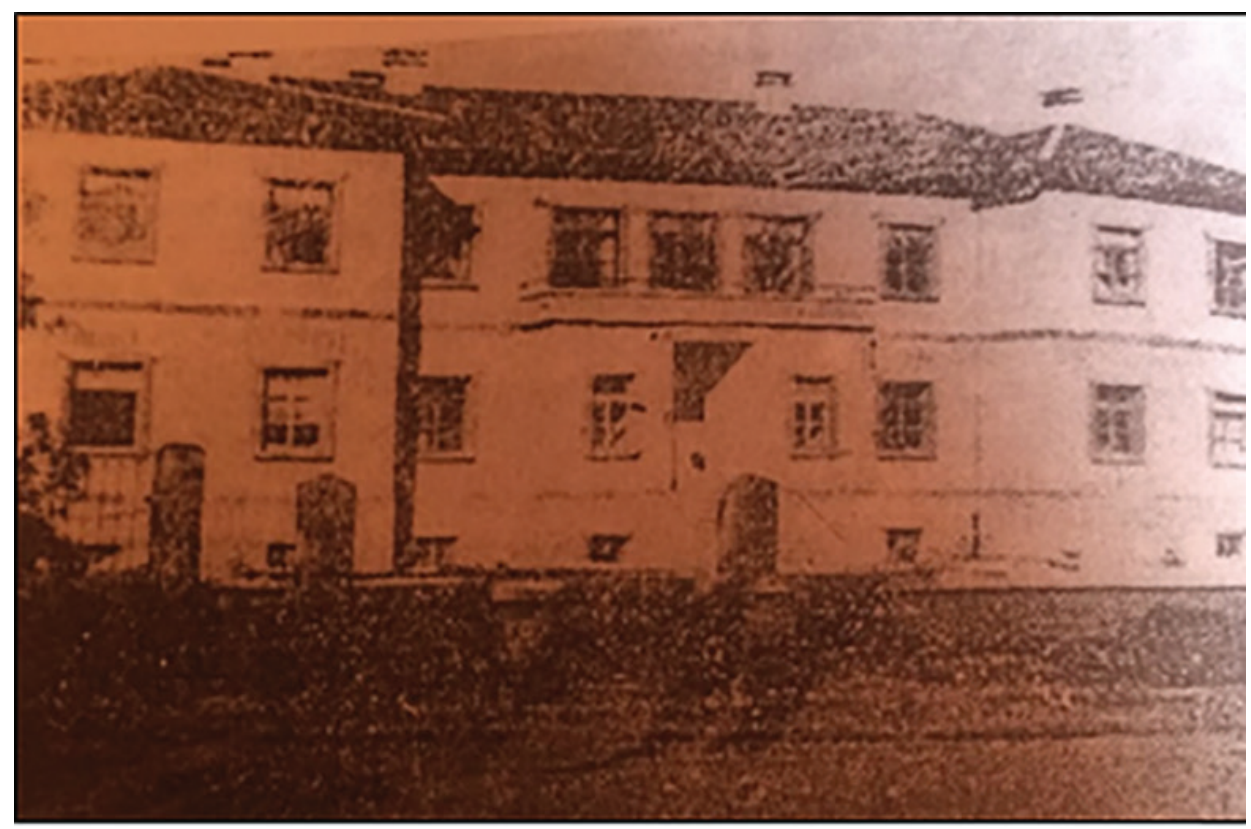

G. 4. Mersin Millet Hastanesi (Develi, Dünden Bugüne Mersin 1836-1990, 128)

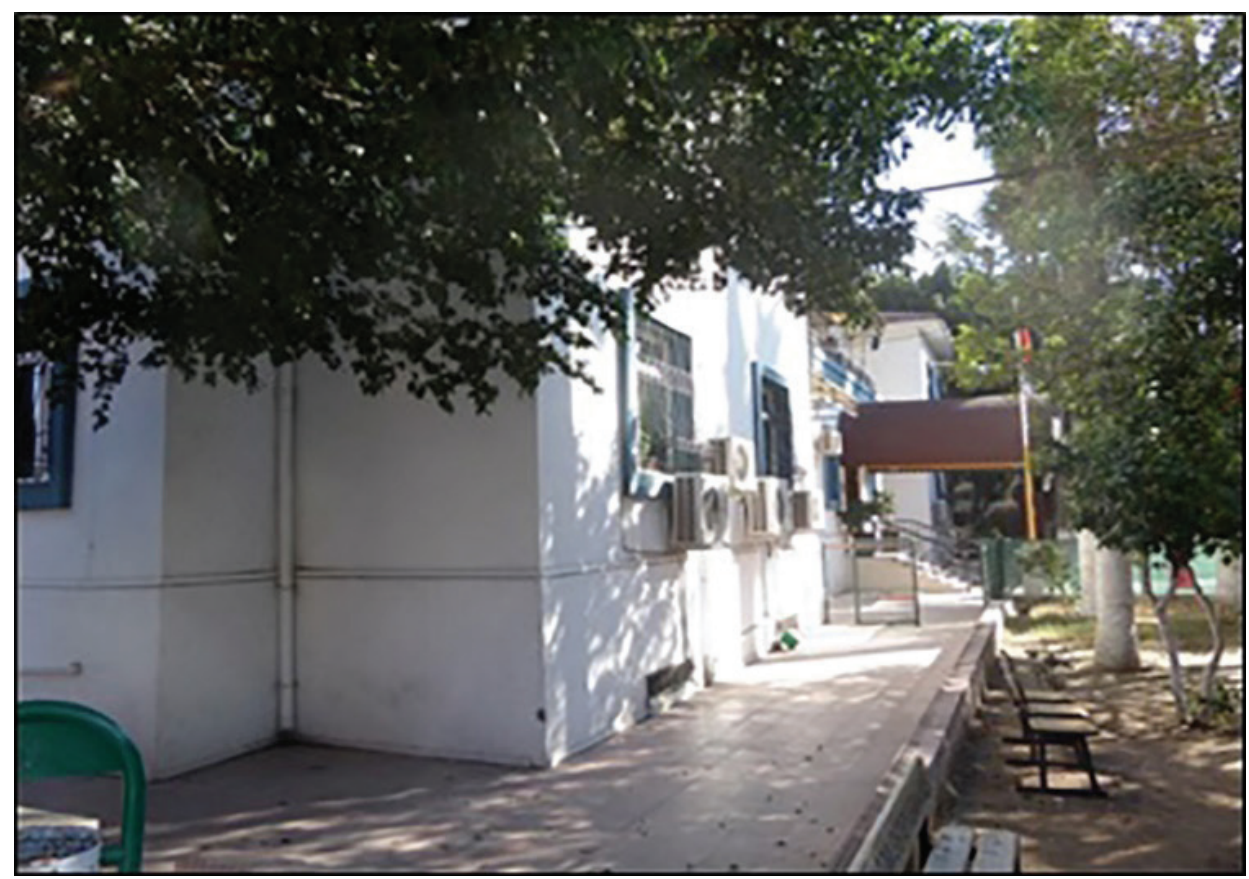

G. 5. Mersin Millet Hastanesi Binas1 (Nur Umar, 2016) 


\section{Silifke Gureba Hastanesi}

Yap1, Mersin ili, Silifke ilçesinde yer almaktadır. 12 Ağustos 1915 yılında inşaatı tamamlanarak Gureba Hastanesi olarak kullanıma açılmıştır ${ }^{32}$. Yapı dikdörtgen planlı, tek katlı ve teras çatılıdır. Ana girişin açıldığ 1 I formunda bir koridor ve koridorun iki yanında yer alan odalardan oluşmaktadır. Cephesi giriş aksına göre simetriktir. Cephenin ortasında yer alan sivri kemerli giriş kapısına sekiz basamakla ulaşılmaktadır. Kapının her iki yanında üçer adet sivri kemerli pencere yer almaktadır. Yapının pencere ve kapıları söveli olup, pencerelerin dış kısmı demir korkuluklar ile kapatılmıştır. Yapı, yığma - kâgir yapım tekniği ile inşa edilmiştir. Yapının dış cephesinin sıvalı olması nedeniyle yapı malzemesi hakkında yeterli bilgiye sahip olunamamıştır. İç mekânda yer döşeme kaplaması olarak fayans kullanılmıştır. Pencere doğramaları PVC, iç mekân kapı doğramaları ahşap, giriş kapısının doğraması ise metaldir. Yap1, günümüzde varlığını sürdürmekte olup taşıyıcı sisteminin iyi durumda olduğu görülmektedir. Cephesi büyük oranda özgün karakterini korumakla birlikte batı yan cephesindeki betonarme ekler ve yenilenen iç mekânlardan, yapının bugüne kadar çeşitli müdahaleler geçirdiği anlaşılmaktadır. Günümüzde Silifke Devlet Hastanesi Başhekimliği olarak kullanılmakta olup sıva ve boyaları yenilenmiş, pencere-kapı doğramaları değiştirilmiş ve pencerelerinin önüne demir korkuluklar eklenmiştir. Ana giriş kapısına açılan dış merdivenin yeniden yapıldığı, cephelerinde yer alan klima donatılarının ve kabloların görüntü kirliliği oluşturduğu tespit edilmiştir.

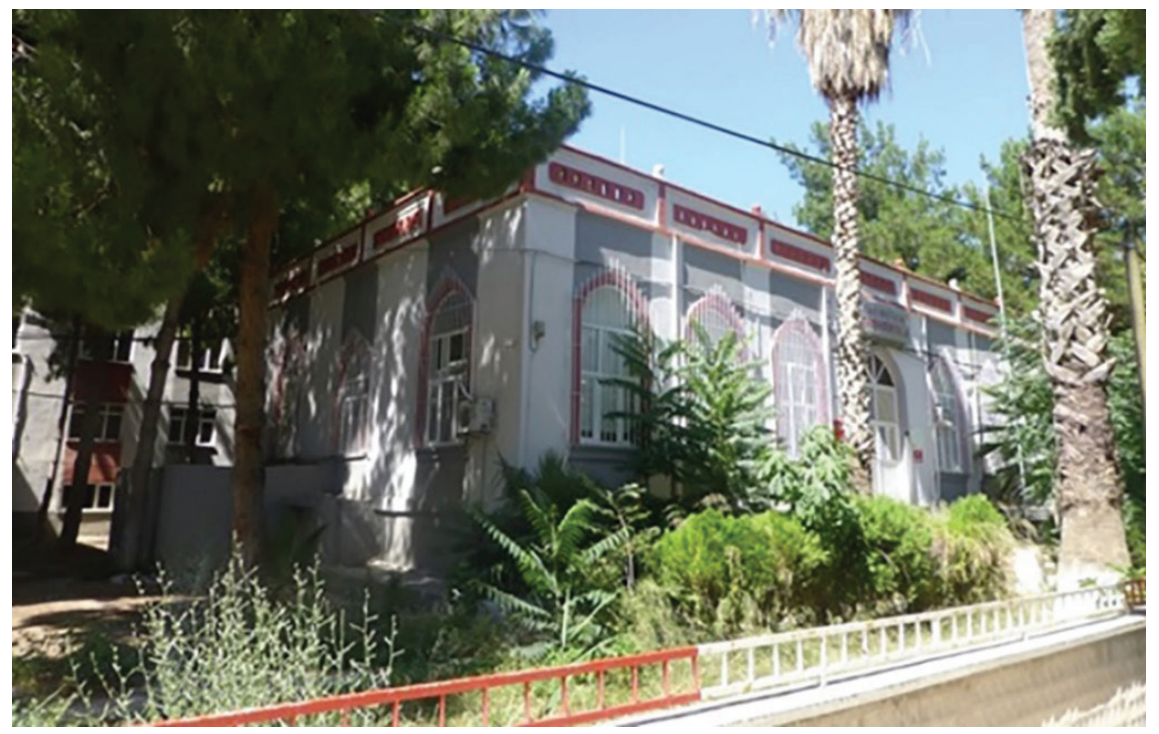

G. 6. Silifke Gureba Hastanesi (Nur Umar, 2014)

32 Ahmet Uçar, Temettuat Defterlerine Göre 19. Yüzyılda Silifke (İstanbul: Silifke Kültür ve Yardımlaşma Derneği Kültür Yayınları, 2009), 79. 


\section{Kozan Eski Hastane}

Yapı, Adana ili, Kozan ilçesi, Hacıuşağı Mahallesi, 324 ada, 1 parsel üzerinde bulunmaktadır. İnşa tarihi, üzerinde yer alan kitabesine göre 1886 yılıdır. Yap1, 12.40x16.60m boyutlarında L planlı ve iki katlıdır. Yapının özgün kısmı dikdörtgen planlı olup, kesme taştan yığma yapım sisteminde inşa edilmiştir. Günümüzde değişime uğrayan yapının kuzeybatısına iki katlı betonarme bir bina eklenerek birinci katta iki bina koridorlarla birleştirilmiştir. Zemin katta, avludan girişi olan iki ayrı oda bulunmaktadır. Solda yer alan sınıf olarak kullanılan oda, dikdörtgen planlı, bir kenarı konveks şeklinde dişa doğru dairesel eğimlidir. Bu odanın içinde sonradan yapılan bölmelerle ikinci bir oda daha oluşturulmuştur. Üst katta ise koridordan üç ayrı odaya geçilebilmektedir. Sol ve ortadaki odanın ön cepheye bakan kısmı bölünerek arşiv odası yapılmış ve ortadaki odadan geçiş sağlanmıştır.

Yapı sıvasız, asimetrik bir cepheye sahiptir. Kuzeyde yer alan ön cephesinde giriş bölümü dairesel olarak öne çıkarılmış, orta aksına basık kemerli giriş kapısı yerleştirilmiştir. Kemerin ortasında yer alan kilit taşı belirginleştirilmiştir. Kilit taşının üstünde yapının kitabesi bulunmaktadır. Kitabenin her iki yanı çiçek motifli bezemelerle süslenmiştir. Dairesel olarak öne çıkan kısımda, giriş kapısının her iki yanında birer adet düz atkılı pencere olduğu görülmektedir. Bu kısmın sol yanına tek katlı betonarme bir ek yapılarak, özgün sol yan cephesi kapatılmıştır. Sağ yanında ise iki adet düz atkılı pencere bulunmaktadır. Yapının köşeleri yumuşak eğrisel hatlarla tamamlanmıştır. Yapının üst kısmında dairesel cumba şeklinde yapılan çıkma, taş profilli konsollarla desteklenmektedir. Çıkmanın altı ahşap ile kaplanmış, konsollar ahşaba oturtulmuştur. Çıkma üzerinde iki adet düz atkılı pencere bulunmaktadır. Pencerelerin üzeri dişli bezeklerle dairesel kemer şeklinde düzenlenmiş, kemerin içi bitkisel formlarla bezenmiştir. Pencerelerin her iki yanında söveyi andıran sütun şeklinde kabartmalar yer almaktadır. Pencerelerin arasında korniş gibi bezemeler, onun altında ise yüzü aşağı dönük ay yıldız ile çiçek kabartması bulunmaktadır. Yan cephelerinin ön cepheye göre daha sade olduğu görülmektedir. Güneyde yer alan arka cephesi günümüzde kullanılan giriş cephesi olmakla beraber, güneybatısına ve doğusuna yapılan eklerle ve okul işlevine uyarlanması için yapılan müdahalelerle özgünlüğünü kaybetmiştir.

Cephe biçimlenişi ve bezemeleri ile Osmanlı kamu mimarisinden farklı olan yapının ilk yapım amacı bilinmemektedir. İşgal yılları ve sonrasında hastane olarak hizmet vermesi nedeniyle eski hastane olarak anılmaktadır. Günümüzde K1z Meslek Lisesi olarak kullanılmakta olduğundan bu işleve uyarlanması için büyük müdahalelere maruz kalmıştır. Güney cephesine batı yönünde betonarme iki katlı ek bir yap1 yapılarak açık bir koridor yardımı ile iki yapı birleştirilmiştir. Sınıfa dönüştürülmek için ilk hâlinde olmayan pencere ve kapılar eklenmiş ve yapılan müdahalelerle güney cephesi tamamen özgünlügünü yitirmiştir. Günümüz okul yapısında güney cephe, ön giriş cephesi olarak kullanılmaktadır. İlk hâlini en çok koruyan kısım kuzey cephesi 
olmasına rağmen, doğu yönünde tek katlı betonarme bir bina eklenerek cephenin zemin katı tamamen kapatılmıştır. Güney cephenin sağ yanında, üst kat duvarı betonarme ve tuğla ile yeniden inşa edilmiştir. Güney cephedeki giriş kapısı kullanılmadığı için tuğla ile kapatılmış, üzeri sıvanmıştır. Zemin kat duvarlarında yer alan taşların üst katlara kıyasla daha çok bozulduğu görülmektedir. Taşların yüzeyinde renk değişimleri ve aşınmalar olmuştur. Dairesel çıkmanın altında yer alan ahşapta bozulmalar ve çürümeler; ahşabın hemen üzerinde bulunan taşlarda da aşınmalar ve kararmalar tespit edilmiştir. Yapının kitabesinin sol yanındaki bezeme yok olmuştur. Yapının kapı ve pencerelerinde özgün doğrama kalmamış, birçoğu pvc ile değiştirilmiştir. Zemin kat pencerelerinin önüne demir korkuluklar eklenmiştir. Yapının cephelerinde görülen yağmur suyu iniş boruları, baca ve klima donatıları gibi elemanlar görüntü kirliliği oluşturarak, yapının algılanmasını zorlaştırmaktadır. Yapı; Kozan'da günümüze ulaşan nadir Osmanlı yapılarından biri olması, Osmanlı'nın son döneminde hastane olarak kullanılması ve özgün mimarisi nedeniyle korunmaya değerdir.
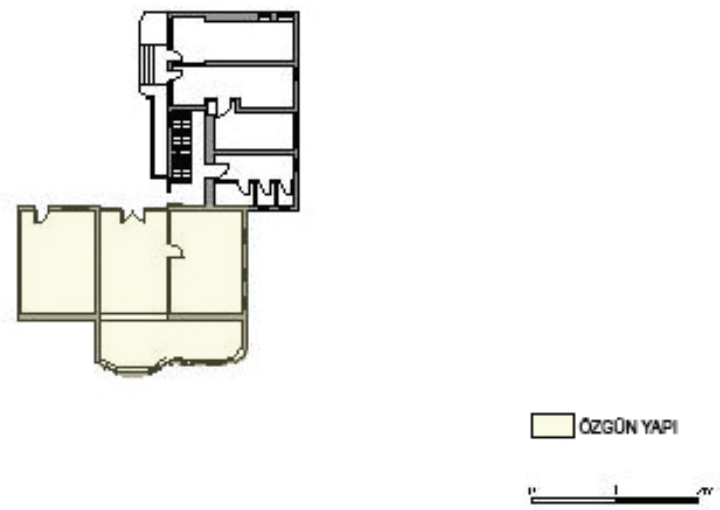

G. 7. Kozan Eski Hastane Zemin Kat Plan1 ${ }^{33}$ (Nur Umar, 2017)

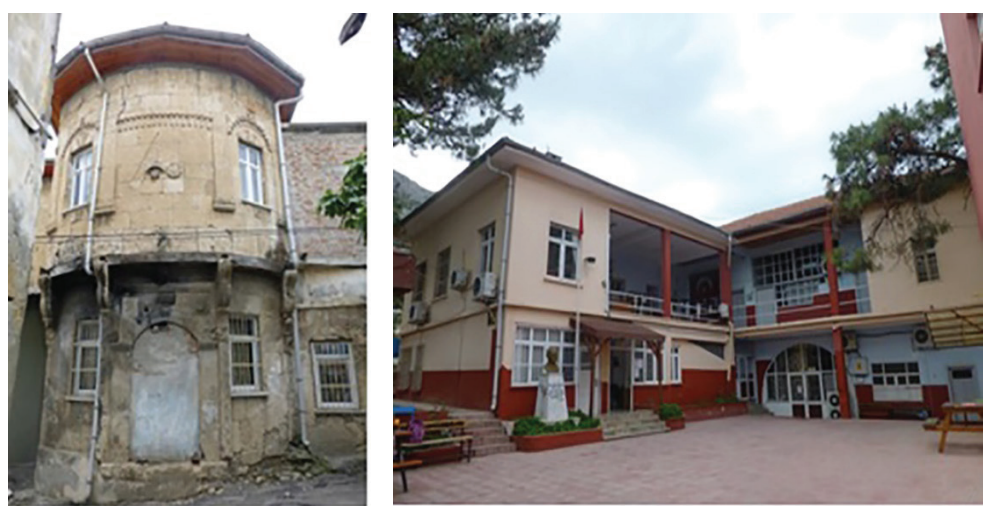

G. 8. Kozan Eski Hastane (Kozan Kız Meslek Lisesi); sol: kuzey cephe, sağ: güney cephe

(Nur Umar, 2015)

33 Adana Kültür Varlıklarını Koruma Kurulu, "Kozan Eski Hastane” dosyasında yer alan rölöveler doğrultusunda yeniden çizilmiştir. 


\section{Tarsus Gureba Hastanesi}

Tarsus'ta ilk hastane 1893 yılında Kaymakam Ziya Bey'in yardımlarıyla yapılmıştır. Bu hastane Adana vilayetinde tespit edilen ilk gureba hastanesidir. İki katlı, büyük bir bina olan yapı, bahçe içinde yer almaktadır. Hastane 50 yatak kapasiteli olup muayene, doktor odaları, eczane ve mutfak bulunmaktadır. Giriş kapısında mevcut olan kitabesinin Latin alfabesine aktarılmış hâli aşağıdaki şekildedir:

“Kaim-makam Ziya'nın ikdam ü gayretiyle

El-hak vücuda geldi bu cay-1 sihhat-abad

Feyz-i lisan-1 fikre geldi tam tarih:

Kıldı kesan-1 belde bimarhaneyi bünyad"34

Günümüzde mevcut olmayan yapının ne zaman yıkıldığına dair bilgiye erişilememiştir.

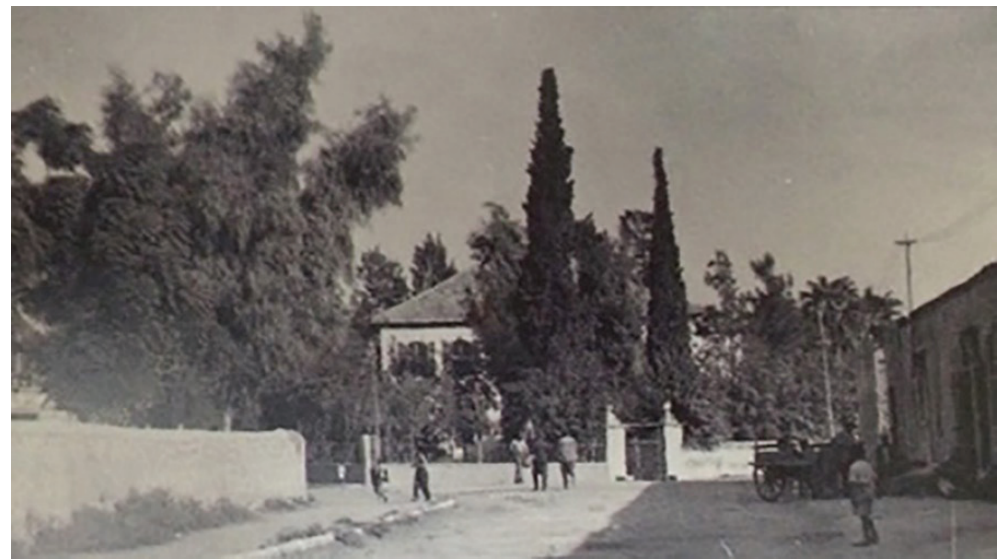

G. 9. Tarsus Gureba Hastanesi, tarih yok (Öz, Yakın Tarihte Tarsus 1850-2000, 55)

\section{Hamidiye (Ceyhan) Gureba Hastahanesi}

1911-13 y1lları arasında Ceyhan kaza merkezinde 40 yataklı bir hastane inşa edilmiş$\operatorname{tir}^{35}$. Günümüzde ayakta olmayan yapıya ait fotoğraf ya da krokilere ulaşılamamıştır.

\section{Adana Belediye Hastanesi}

1898 yılında Bahri Paşa’nın valiliği döneminde, şehirde artan kolera salgınına karşı hastane yaptırma konusu gündeme gelmiştir. Hastane aynı yıl açılmış ancak inşaatı 1906 yılına kadar devam etmiştir ${ }^{36}$. Bu yapıya ait fotoğraf ya da krokilere ulaşılamamıştır.

34 Hikmet Öz, Yakın Tarihte Tarsus 1850-2000 (Adana: Alev Dikici Basım, 2012), 55.

35 Başbakanlık Osmanlı Arşivi (BOA), Dahiliye Hapishaneler Müdiriyeti (DH.MB..HPS..) 19/32, 13/ Ca/1334 (18 Mart 1916).

36 Meltem Toksöz ve Emre Yalçın, “Modern Adana’nın Doğuşu ve Günümüzdeki İzleri”, Abdullah Kuran için Yazılar, ed. Çiğdem Kafesçioğlu ve Lucienne Thys Şenocak (İstanbul: Yapı Kredi Yayınları, 1999), 436-452. 


\section{Değerlendirme}

Adana vilayeti sağlık yapıları farklı parametrelerden incelendiğinde aşağıdaki değerlendirmeler yapılabilmektedir:

Adana vilayetindeki sağlık yapıları, çoğunlukla şehir içinde yerleşim yerlerine yakın fakat onlardan bağımsız noktalarda, genellikle bahçe içerisinde konumlanmışlardır. Adana vilayetindeki sağlık yapıları plan özellikleri olarak iki tipte sınıflandırılabilmektedir: İlk tip, dikdörtgen planlı yapılardır. Bunlar tek yapı şeklinde olabildiği gibi, pavyon şeklinde yayılmış da olabilirler. Adana ve Silifke Guraba Hastaneleri bu tipe örnek oluşturabilmektedir. İkinci tip U planlı yapılardır. Genelde iki katlı olan bu yapılara örnek olarak Mersin Millet Hastanesi gösterebilir. Adana vilayetinde tespit edilen sağlık yapılarında kışla plan tipine rastlanmamıştır.

Adana vilayeti sağlık yapıları, yığma yapım tekniği ile inşa edilmiş olup günümüze ulaşan yapıların sayılarının azlığı nedeniyle cephe özellikleri açısından sınıflandırılmaları güçtür. Bu nedenle tespit edilen yapılar, ulaşılan veriler doğrultusunda cephe örnekleri yönünden tablo hâline getirilmiştir (G. 11). Ortak özelliklerine bakıldığında bir ya da iki kattan oluşmuş, giriş aksına göre simetrik tarzda biçimlenen cephelerle karşılaşılmaktadır. Pencere ve kapılar genelde kemerlidir. Sadece Millet Hastanesi’nin cepheleri düz atkılı, etrafı söve ile çevrilmiş pencere ve kapılardan oluşmaktadır.

Adana vilayetinde merkez ve sancaklar dâhil olmak üzere 7 sağlık yapısı tespit edilmiştir. Tespit edilen 7 yapının sadece 3’ü günümüze ulaşmıştır. Bu verilere göre sağlık yapılarının yarıya yakın bir oranın korunabildiği anlaşılmaktadır. Bu yapıların günümüzdeki kullanımlarına bakıldığında sadece iki yapının hastane kompleksinin içerisinde kaldığını görülmektedir. Bunlardan biri sağlıkla ilgili işlevini sürdürürken, bir yapı da işlevsizdir. Hastane kompleksinin dişında yer alan tek yapı ise okul olarak kullanılmaktadır. Adana Gureba Hastanesi, Tarsus Gureba Hastanesi, Hamidiye (Ceyhan) Gureba Hastanesi ve Adana Belediye Hastanesi günümüze ulaşmamıştır. Hastane yapılarının büyüme ihtiyacı ve eski yapıların yeni donanımlar için yetersiz kalmasından ötürü yeni binalar yapılmıştır. Hastane kompleksleri içerisinde kalan eski yapılar işlevlerini yitirmelerinden ötürü korunamamışlardır.

Günümüze ulaşan yapılar kendi aralarında özgünlük ve taşıyıcı yapı durumları açısından kendi aralarında iyi, orta ve kötü olarak sınıflandırılmıştır. Günümüzde ayakta olan sağlık yapıları büyük çoğunluğu özgünlük açısından orta düzeydedir. Cephe düzenlerini korumakla beraber kat eklenmesi, iç mekân planında değişiklik, kapı ve pencere doğramalarının yenilenmesi gibi müdahaleler gördükleri tespit edilmiştir. 


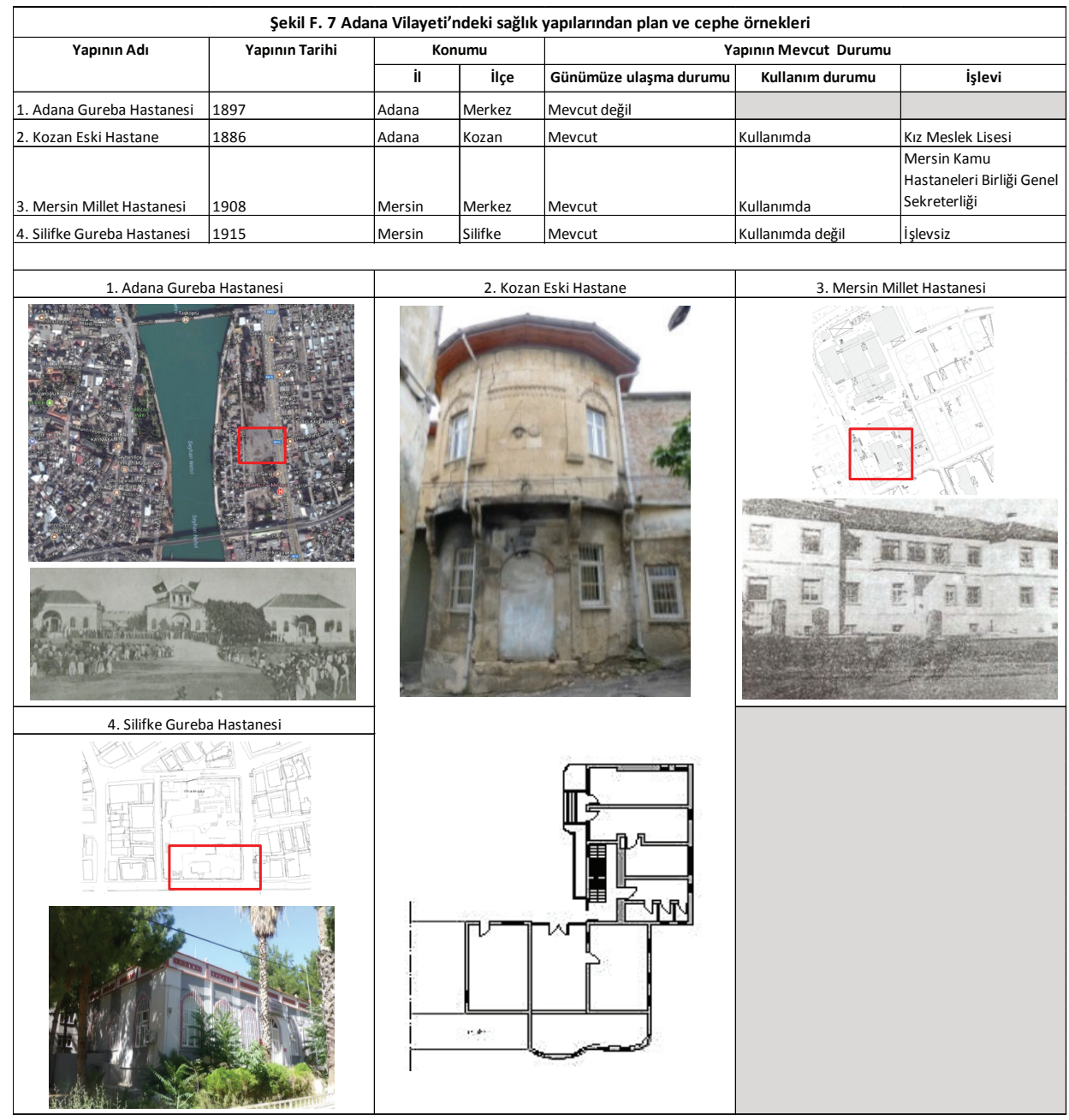

G. 10. Plan ve cephe örnekleri ${ }^{37}$ (Nur Umar, 2017)

37 Planlar sırasıyla, maps.google.com, Nur Umar (2017); Mersin Belediyesi Halihazır Haritasi; Silifke Belediyesi Halihazır Haritası; yapı fotoğrafları sırasıyla, Servet-i Fünun Dergisi 342, 18 Eylül 1313 (1894), 54; Nur Umar (2015); Develi, Dünden Bugüne Mersin (1836-1990), 128; Nur Umar (2014). 


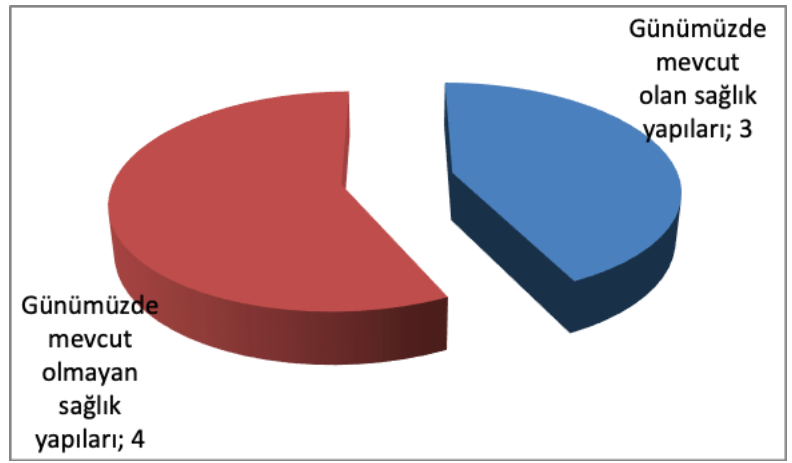

G. 11. Sağlık Yapılarının Günümüzde Mevcut Olma Durumları (Nur Umar, 2017)

\section{Sonuç}

Osmanlı devletinde 19. yüzyılda kamusal alanda yaşanan değişim ve dönüşümler sağlık alanında da büyük ölçüde hissedilmiştir. Geleneksel sağlık kurumları darüşşifalardan dönemin modern hastanelerine doğru bir geçiş yaşanmıştır. Halk için modern sağlık anlayışının temeli Gureba hastaneleri ile Tanzimat Dönemi'nde başlamış olsa da, sosyal devlet anlayışının kurumsallaşması büyük ölçüde II. Abdülhamit döneminde gerçekleşmiştir. Kurumsallaşan bu yapılar, Hamidiye Hastaneleri devamında ise Millet Hastanesi, Belediye Hastanesi vb. isimlerle karşımıza çıkmaktadır. İlk hastane örnekleri başkent İstanbul ve çevresinde görülse de artan ihtiyaç (salgın hastalıklar, savaş, iç çatışmalar vb.) nedeni ile Anadolu'da da inşa edilmeye başlanmıştır. Osmanlı Devleti'nde sağlık yapılarının gelişimi, yeni ihtiyaçları karşılamak amacıyla çağın teknolojik imkânlarından yararlanmayı hedefleyen bir anlayış doğrultusunda gerçekleşmiş, yapıların planları ihtiyaç-işlerlik doğrultusunda şekillenirken, cepheleri dönemin mimari anlayışıyla uyumlu olarak tasarlanmıştır. En sık rastlanan plan şemaları kışla, pavyon ve U tipi olmuştur. Çalışma kapsamında Osmanlı Devleti'nin sağlık yapılarındaki değişim başkentteki yapılar üzerinden genel olarak incelenmiştir. Sonrasında ise 19. yüzyılda Osmanlı Devleti içerisinde önemi artan Adana vilayeti özelinde tespit edilen sağlık yapıları değerlendirilmiştir. Bu örneklerden yola çıarak hastane yapılarının İstanbul'daki örnekler kadar gösterişli ve zengin plan çeşitliliğine sahip olmasa da Adana vilayetinde de benzer tipoloji ve üsluplarla inşa edildiği görülmektedir. Fakat tespit edilen yapıların nicelik olarak az oluşu, bu vilayet özelinde yapılarla ilgili net yargılara ulaşmayı ve tipolojik karşılaştırmalar yapılmasını zorlaştırmaktadır. Yapılar vilayet genelinde her sancakta en az bir hastane yapısı olacak şekilde dağılım göstermiş, yalnızca Cebel-i Bereket Sancağı'nda Osmanlı devleti tarafından yaptırılan herhangi bir hastane yapısı tespit edilememiştir. Bu durum bölgede geleneksel konutların da hastane olarak kullanıldığını düşündürmektedir.

Günümüze sadece üç sağlık yapısı ulaşabilmiş olup ikisinin özgün işlevlerini yitirmelerine karşın etkin bir şekilde kullanıldıkları ve restorasyon geçirdikleri için taşıyıcı 
yapı olarak orta durumda oldukları görülmüştür. Sadece bir yapı taşıyıcı olarak iyi durumda fakat kullanılmamaktadır. Bu yapıların Adana vilayetindeki hastane yapılarının ilk örnekleri olmaları, geç Osmanlı mimarisini yansıtmaları ve bu döneme ait plansal gelişime, yapım sistemlerine örnek oluşturmaları nedeniyle korunmaları; işlevsiz olanlarının yeniden işlevlendirilerek geleceğe aktarılmaları önerilmektedir.

Hakem Değerlendirmesi: Dış bağımsız.

Çıkar Çatışması: Yazarlar çıkar çatışması bildirmemiştir.

Finansal Destek: Yazarlar bu çalışma için finansal destek almadığını beyan etmiştir.

Peer-review: Externally peer-reviewed.

Conflict of Interest: The authors have no conflict of interest to declare.

Grant Support: The authors declared that this study has received no financial support.

\section{Kaynakça/References}

“Adana Gureba Hastanesi Fotoğrafi.” Servet-i Fünun Dergisi 342 (18 Eylül 1313 [1894]): 54.

Balsoy, Gülhan. "Bir Kadın Hastanesi Olarak Haseki Hastanesi ve 19. Yüzyıl İstanbul'unda Bikes ve Bimesken Bir Kadın Olmak.” Toplumsal Tarih Dergisi 257 (Mayıs 2015): 80-84.

Cantay, Gönül. "Darüşşifalar.” Mimar Başı Koca Sinan Yaşadiğı Çăg ve Eserleri. 1. cilt. İstanbul: T.C. Başbakanlık Vakıflar Genel Müdürlüğü Yayınları, 1988, 355-368.

Cantay, Gönül. “Osmanlı Mimarisinde Darüşşialar”. Prof. Dr. Ali Haydar Bayat Anısına Düzenlenen Osmanlı Sağlık Kurumları Sempozyumu Haziran 2007. İstanbul, Zeytinburnu Belediyesi Yayınları, 2008, 67-80.

Cantay, Gönül. Anadolu Selçuklu Ve Osmanlı Darüşşifaları. Ankara: Atatürk Kültür Merkezi Yayınları, 2014.

Çiftçi, Aynur. “19. Yüzyılda Osmanlı Devleti'nde Askeri Mimari ve İstanbul'da İnşa Edilen Askeri Yapılar.” Doktora tezi, Yıldız Teknik Üniversitesi, 2004.

Çobanoğlu, Ahmet Vefa. "Yok Olan Bir Yapı Sultanahmed Darüşşifası." Sanat Tarihi Araştırmaları Dergisi 2 (1988): 35-39.

Demirhan, Bahar. “Zeynep Kâmil Hastahanesi Restorasyon Projesi.” Yüksek Lisans tezi, İstanbul Teknik Üniversitesi, 2005.

Develi, H. Şinasi. Dünden Bugüne Mersin (1836-1990). Mersin: Mersin Ticaret Odası Yayınları, 2001.

Ekter, Şeref ve Feza Günergun. "Zeynep-Kamil Hastanesi (1875): Romantik Tarihçiliğin Gölgesinden Bir Çıkış Denemesi”. Prof. Dr. Ali Haydar Bayat Anısına Düzenlenen Osmanlı Sağlık Kurumları Sempozyumu Haziran 2007. İstanbul, Zeytinburnu Belediyesi, 2008, 147-169.

Güntan, Çağrı, "II. Abdülhamit Döneminde İmparatorluk İmajının Kamu Yapıları Aracılığı İle Osmanlı Kentine Yansıtılması.” Yüksek Lisans tezi, Yıldız Teknik Üniversitesi, 2007.

Güreşsever Cantay, Gönül. “XIX. Yüzyılda Kurumlaşma ve Hastahaneler I.” FSM İlmi Araştırmalar Insan ve Toplum Bilimleri Dergisi 1 ( Bahar 2013): 108-126.

Güreşsever Cantay, Gönül. “XIX. Yüzyılda Kurumlaşma ve Hastahaneler II.” FSM İlmi Araştırmalar Insan ve Toplum Bilimleri Dergisi 2 (Güz 2013): 57-73. 
K1lıç, Abdullah. Anadolu Selçuklu ve Osmanlı Şefkat Abideleri Şifahaneler. İstanbul: Medialpark, 2012.

Mursal, Seçil. “Osmanlı Devleti’nde İlk Guraba Hastaneleri.” Yüksek Lisans tezi, Cumhuriyet Üniversitesi, 2017.

Öz, Hikmet. Yakın Tarihte Tarsus (1850-2000). Adana: Alev Dikici Basım, 2012.

Sarıyıldız, Gülden. “Karantina.” TDV İslam Ansiklopedisi. 24. cilt. İstanbul: Türkiye Diyanet Vakfı Yayınları, 2001, 463-465.

Toksöz, Meltem ve Emre Yalçın. “Modern Adana'nın Doğuşu ve Günümüzdeki İzleri”. Abdullah Kuran İçin Yazılar. Ed. Çiğdem Kafesçioğlu ve Lucienne Thys Şenocak. İstanbul: Yapı Kredi Yayınlar1, 1999, 436-452.

Uçar, Ahmet. Temettuat Defterlerine Göre 19. Yüzyılda Silifke. İstanbul: Silifke Kültür ve Yardımlaşma Derneği Kültür Yayınları, 2009.

Umar, Nur. “19. Yüzyılda Adana Vilayetindeki Kamu Yapıları.” Doktora tezi, Yıldız Teknik Üniversitesi, 2017.

Yavuz, Yıldırım. "Batılaşma Döneminde Osmanlı Sağlık Kuruluşları.” ODTÜ Mimarlık Fakültesi Dergisi 8/2 (1988): 123-142.

Yıldırım, Nuran. Hastane Tarihimizde Bir Kutup Yıldızı Hamidiye Etfal Hastanesi. İstanbul: Ajansfa, 2010.

Yıldırım, Nuran. Tarihi Sağlık Kurumlarımız Darüşşifalar. 2. cilt. İstanbul: Ajansfa, 2010.

Başbakanlık Osmanlı Arşivi (BOA), Yıldız Mütenevvi Maruzat (Y..MTV.) 175/317, 23/ Za/1315 (14 Nisan 1898).

Başbakanlık Osmanlı Arşivi (BOA), Dahiliye Hapishaneler Müdiriyeti (DH.MB..HPS..) 19/32, 13/ $\mathrm{Ca} / 1334$ (18 Mart 1916).

https://www.houshamadyan.org/mapottomanempire/vilayet-of-adana.html. Erişim 20 Mayıs 2017

http://haritalar.istanbul.edu.tr/viewer.php?tileCode=92617. Erişim 8 Kasım 2019

https://www.facebook.com/abdulhamideah/. Erişim 8 Kasım 2019

https://www.emlaklobisi.com/bilgi-bankasi/haydarpasa-numune-egitim-ve-arastirmahastanesi -90444. Erişim 8 Kasım 2019

http://abdulhamid.site/abdulhamid-ve-eserleri/abdulhamid-donemi-hastaneler/haydarpasa-numunehastanesi/ . Erişim 8 Kasım 2019

http://bezmialem.edu.tr. Erişim 8 Kasım 2019

https://zeynepkamilkdch.saglik.gov.tr/TR,87631/tarihcemiz.html. Erişim 8 Kasım 2019 
